\title{
INDOOR AIR QUALITY STUDY USING LOW-COST SENSORS
}

\author{
MYRIAM LOPES, JOHNNY REIS, ANA P. FERNANDES, DIOGO LOPES, RÚBEN LOURENÇO, \\ TERESA NUNES, CARLOS H. G. FARIA, CARLOS BORREGO \& ANA I. MIRANDA \\ CESAM and Department of Environment and Planning, University of Aveiro, Portugal
}

\begin{abstract}
People spend about $90 \%$ of their time in indoor environments without really knowing about the quality of the air in these spaces. This lack of knowledge about the indoor air quality and the exposure time can aggravate the health conditions of the individuals in the indoor spaces of houses. The aim of this study was to study the feasibility of using low-cost sensors to quantify and to identify the main causes of poor indoor air quality. For this purpose, three houses with different locations were chosen, either regarding the surrounding environment or the behaviour of residents. Micro sensors for the main indoor air quality pollutants $\left(\mathrm{CO}, \mathrm{CO}_{2}, \mathrm{PM}_{10}, \mathrm{PM}_{2.5}, \mathrm{NO}_{2}\right.$ and $\left.\mathrm{Ox}\right)$ were selected to build a sensor box. Bedrooms and living rooms were monitored for approximately seven months, from September 2019 to March 2020. Several associations between pollutants concentrations and occupant's activity patterns or outdoor conditions were identified. Results showed that pollutants present in indoor air may also vary according to the season and their concentrations may also vary with outdoor air quality conditions. Results also showed that the determinants of indoor air concentrations varied considerably among different types of pollutants. The geographic location and surrounding environment of the house, resident's behaviour and time-activity (space heating, ventilation or cooking) can change pollutants concentrations and therefore indoor air quality.
\end{abstract}

Keywords: indoor air quality, micro sensors, air quality monitoring, smart homes.

\section{INTRODUCTION}

Ambient and household air pollution rank among the ten leading causes of death and morbidity globally [1]. Nowadays, people spend in average approximately $90 \%$ of their time in indoor environments, being exposed to indoor air pollutants for larger periods than those outdoors [2]. Therefore, it is crucial to characterise and monitor the indoor air, in order to understand its composition and, in the presence of potential harmful concentrations of chemical species, dangerous for human health, identify possible causes for them (direct or indirect sources of pollutants) [3]. In 2016, indoor exposure has been associated with several health issues, such as respiratory diseases, and 3.8 million deaths, globally [4].

The pollutants usually analysed in Indoor Air Quality (IAQ) monitoring include carbon dioxide $\left(\mathrm{CO}_{2}\right)$, carbon monoxide $(\mathrm{CO})$, formaldehyde $\left(\mathrm{CH}_{2} \mathrm{O}\right)$, total volatile organic compounds (VOC), particulate matter (PM) and, at the microbiological level, bacteria and fungi [5].

The World Health Organization [5] states that IAQ management is hampered, not only because of the numerous types of indoor spaces, but also due to complex relationships between IAQ and building design, materials, operation and maintenance, ventilation and user behaviour. Both the Portuguese Environmental Agency [6] and the United States Environmental Protection Agency [7], consider construction materials and consumer products the most important sources contributing to the degradation of IAQ. Other common causes of poor IAQ are coating and furniture materials, human occupancy, combustion sources (oil, natural gas, kerosene, coal, wood and tobacco), asbestos, heating and cooling systems, humidification devices and the infiltration of outdoor pollutants.

The current legislation specifies protection thresholds for some pollutants to improve IAQ. IAQ legislation is also interlinked with energy performance of buildings regulation. 
The Directive 2002/91/EC and later the Directive 2010/31/UE, which aim to promote buildings energy performance, were implemented. Both Directives take into account outdoor climate and local conditions, as well as indoor climate requirements and cost-effectiveness. In Portugal, the first Directive was adopted as three Decrees-Law, which, directly or indirectly, seek to improve IAQ by promoting an adequate air exchange of the spaces. The first, Decree-Law no. 78/2006 of 4th April, approved the National Energy Certification and Indoor Air Quality in Buildings; the second, Decree-Law no. 79/2006 of 4th April, approved the Regulation of Climate Energy Systems in Buildings (RCESB); and, finally, the third, Decree-Law no. 80/2006 of 4th Apr., approved the Regulation Characteristics of Thermal Performance of Buildings.

After the second European Community Directive, the previous Portuguese decrees were revised and merged into the Decree no. 118/2013 of 20th August and subsequent regulated ordinances. In the RCESB context, the requirements to improve IAQ range from the imposition of a minimum value of air exchange rate, applicable to the new buildings, to the definition of concentration thresholds for several pollutants (e.g. $\mathrm{CO}, \mathrm{CO}_{2}$, VOC and PM). The RCESB also requires that all energy systems constructed or existing in buildings to be kept in hygienic conditions.

During recent years, low-cost sensors have emerged as a cost-efficient alternative to the precision equipment, normally used in long-term air pollution monitoring [8]-[11]. Low-cost air pollution sensors have inherent limitations and uncertainties regarding precision, unambiguity and long-term stability [8], [10], [12]. On the other hand, low-cost sensors allow to deploy a much higher number of units, mobile deployment and their size make them suitable to be used in micro-environments, where traditional equipment would be too disturbing. Especially, the latter property might make low-cost sensors very useful for characterising indoor air pollution. For the majority of low-cost sensors, the raw output signal is not quantitative and may vary between individual devices by a scaling factor. Therefore, each instrument needs to be calibrated by comparison with reference instrumentation.

The main objective of this work was to study the feasibility of using low-cost sensors to quantify IAQ parameters, by using low-cost micro sensor in bedrooms and living rooms. The paper is organized as follows: Section 2 describes the case study and the approach used in this work; in Section 3, the comparison results between measurements by sensor boxes and certified equipment are presented; in Section 4, a summary and conclusions are presented.

\section{METHODOLOGY}

\subsection{Indoor air quality sensor boxes}

The low-cost indoor air quality (IAQ) monitoring stations were built using well establish commercial micro sensors specific for different pollutants according to characteristics presented in Table 1. The difference between Oxidising Gases and Nitrogen Dioxide is considered to be mainly Ozone. Two types of IAQ were developed to be installed, respectively, in bedrooms (basic) and living rooms (more complete). All IAQ were equipped with sensors for temperature, relative humidity, and communication board and motherboard for data communication and data storage, respectively (Fig. 1(a)). The IAQ sensor boxes were designed to be powered at $5 \mathrm{~V}$. Data measured and reported by sensor boxes was obtained using an Application Programming Interface (API).

To protect the sensors, a sensor box model was designed and printed on a 3D printer, with ADS/PLA (plastic). The final architecture of the sensor boxes is shown in Figs 1 and 2. 
Table 1: Main features of the indoor air quality monitoring stations (sensor boxes).

\begin{tabular}{|c|c|c|c|c|}
\hline Parameter & Micro sensor type & Technology & Range & Site \\
\hline Particulates $\left(\mathrm{PM}_{10}\right)$ & Gassensor & Laser scattering & $0-500 \mu \mathrm{g} \cdot \mathrm{m}^{-3}$ & $\begin{array}{l}\text { Bedroom/living } \\
\text { room }\end{array}$ \\
\hline Particulates $\left(\mathrm{PM}_{2.5}\right)$ & Gassensor & Laser scattering & $0-500 \mu \mathrm{g} \cdot \mathrm{m}^{-3}$ & $\begin{array}{l}\text { Bedroom/living } \\
\text { room }\end{array}$ \\
\hline $\begin{array}{l}\text { Carbon Dioxide } \\
\left(\mathrm{CO}_{2}\right)\end{array}$ & Alphasense & $\begin{array}{l}\text { Non-dispersive } \\
\text { infra-red }\end{array}$ & $700-4000 \mathrm{mg} \cdot \mathrm{m}^{-3}$ & $\begin{array}{l}\text { Bedroom/living } \\
\text { room }\end{array}$ \\
\hline $\begin{array}{l}\text { Nitrogen dioxide } \\
\left(\mathrm{NO}_{2}\right)\end{array}$ & Alphasense & $\begin{array}{l}\text { Electrochemical } \\
\text { sensor }\end{array}$ & $5-500 \mu \mathrm{g} \cdot \mathrm{m}^{-3}$ & Living room \\
\hline $\begin{array}{l}\text { Oxidising Gases } \\
\left(\mathrm{O}_{\mathrm{X}}\right)\end{array}$ & Alphasense & $\begin{array}{l}\text { Electrochemical } \\
\text { sensor }\end{array}$ & $5-500 \mu \mathrm{g} \cdot \mathrm{m}^{-3}$ & Living room \\
\hline $\begin{array}{l}\text { Carbon Monoxide } \\
\text { (CO) }\end{array}$ & Alphasense & $\begin{array}{l}\text { Electrochemical } \\
\text { sensor }\end{array}$ & $0.1-15 \mathrm{mg} \cdot \mathrm{m}^{-3}$ & Living room \\
\hline Temperature & Texas instruments & Linear tension & $-40^{\circ} \mathrm{C}-+60^{\circ} \mathrm{C}$ & $\begin{array}{l}\text { Bedroom/living } \\
\text { room }\end{array}$ \\
\hline Relative humidity & Sigma sensors & Presence of moisture & $5 \%-100 \%$ & $\begin{array}{l}\text { Bedroom/living } \\
\text { room }\end{array}$ \\
\hline
\end{tabular}

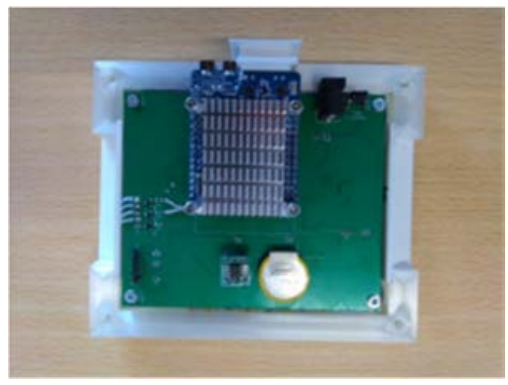

(a)

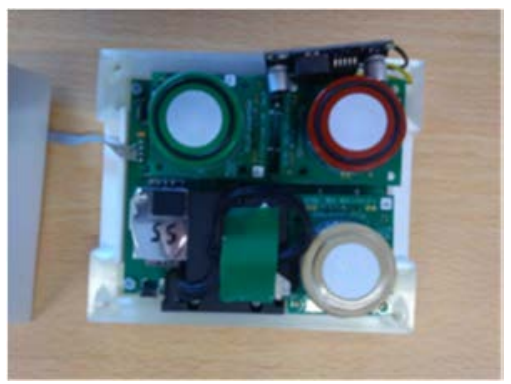

(b)

Figure 1: (a) Bedroom; and (b) Living room sensor boxes architecture.

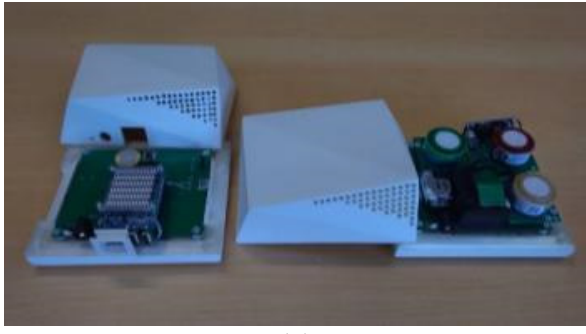

(a)

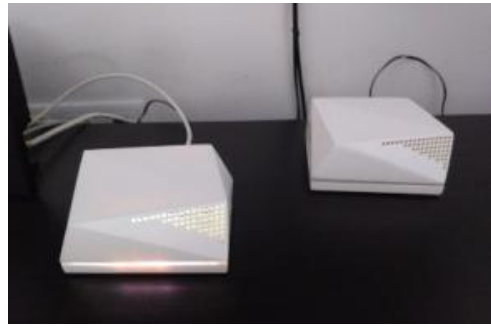

(b)

Figure 2: Final sensor boxes layout. (a) Open; and (b) Closed.

\subsection{Monitoring sites}

To carry out this study, three homes in three different locations were selected (Fig. 3). In each home, two sensor boxes were installed, in the living room and in a bedroom. 


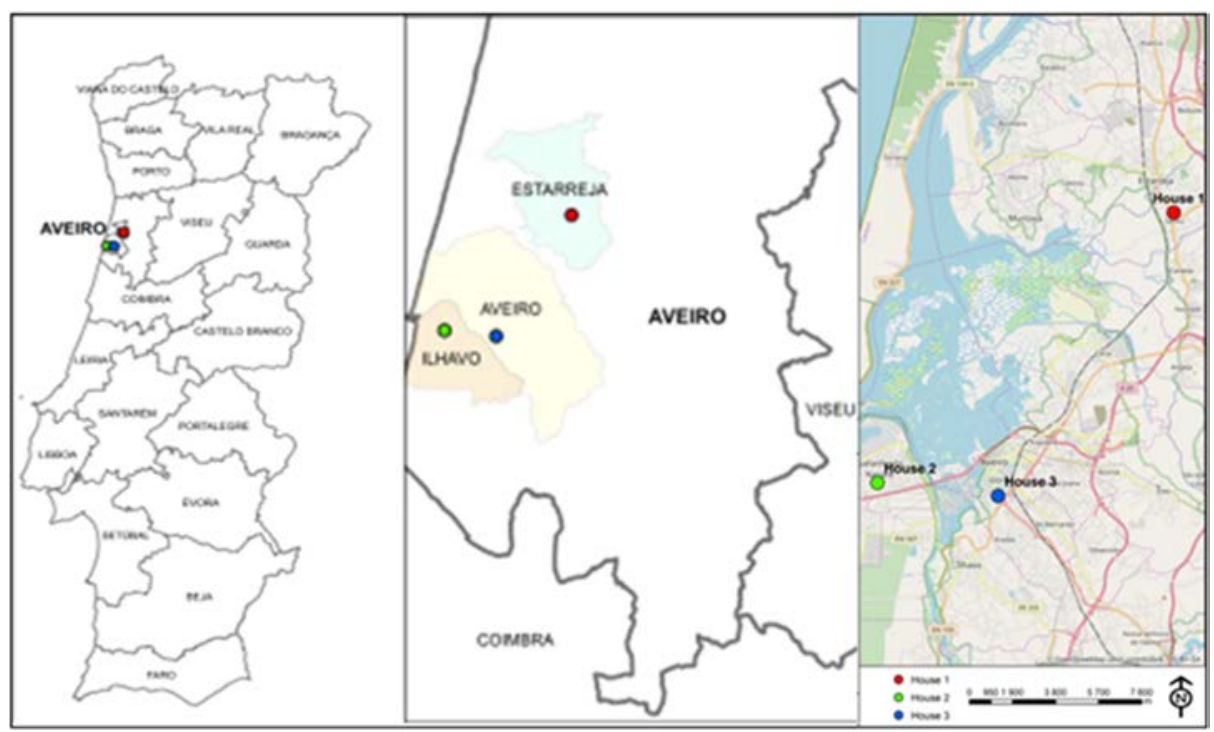

Figure 3: Sensor boxes location.

Home 1 is an apartment located in Salreu, Estarreja, an industrialized urban area and next to an important road traffic line (National road 109). The residents are a couple with a child. Both elements of the couple are workers with well-defined weekly routines, leaving the house in the morning and returning in the late afternoon. On weekends, Saturdays are reserved for cleaning activities and Sundays are dedicated to rest and family life.

Home 2 is a house located in Gafanha da Nazaré, Ílhavo, in a residential suburban area and next to a high school. The occupants are a couple and two teenager's family. The couple leaving the house in the morning and returning in the late afternoon. Teenager's occupancy regime is dependent on their class schedule. A house cleaner performs cleaning activities every morning from Monday to Friday. During the weekend, the family often leave home to go shopping and to participate in sports and leisure activities.

Home 3 is an apartment located in Aveiro, in a residential area close to Aveiro District Hospital and University of Aveiro). The tenants consist of a family composed by a couple with no children, with a well-defined weekly routine, leaving home in the morning and returning in the late afternoon. On weekends, Saturdays are reserved for cleaning and Sundays are dedicated to rest and family life.

\subsection{Intercomparision field tests}

The sensor boxes were tested against two commercial reference equipment used to assess IAQ. Both devices performed a series of measurements side by side, during two days in the bedroom and five days in the living room of Home 1 and 2. During these tests, continuous measurements of $\mathrm{CO}, \mathrm{CO}_{2}, \mathrm{NO}_{2}, \mathrm{O}_{3}, \mathrm{PM}_{2.5}, \mathrm{PM}_{10}$, temperature $(\mathrm{T})$ and relative humidity $(\mathrm{RH})$ were performed. For gas monitoring, two commercial reference instruments were used: GrayWolf $^{\mathbb{B}}$ (IQ-610 and TG-501) and the YESAIR 8-Channel IAQ Monitor. The commercial monitor employed to quantify particulate matter was the GrayWolf ${ }^{\circledR}$ PC-3016A. During the intercomparison field tests, the air pollutants were measured with a time-step of 15 minutes. 
The technology behind the YESAIR monitor and the IQ-610 and TG-501 probes are based on electrochemical gas sensors $\left(\mathrm{CO}, \mathrm{NO}_{2}\right.$ and $\left.\mathrm{O}_{3}\right)$ and non-dispersive infrared sensors $\left(\mathrm{CO}_{2}\right)$ [13], [14]. The PC-3016A is a light-scattering laser photometer that records particulate matter concentrations $\left(\mathrm{PM}_{0.3}, \mathrm{PM}_{0.5}, \mathrm{PM}_{1}, \mathrm{PM}_{2.5}, \mathrm{PM}_{5}\right.$ and $\left.\mathrm{PM}_{10}\right)$ [15], [16]. Detailed information for each commercial reference instrument can be found in Table 2, including the detection ranges and accuracies.

Table 2: Specifications of the reference instruments used in the intercomparison test.

\begin{tabular}{|c|c|c|c|c|c|}
\hline Equipment & Parameter & Range & $\begin{array}{c}\text { Detection } \\
\text { limit }\end{array}$ & $\begin{array}{l}\text { Accuracy/Counting efficiency/ } \\
\text { Uncertainty }\end{array}$ & References \\
\hline \multirow{4}{*}{$\begin{array}{l}\text { IQ-610 - } \\
\text { GrayWolf }^{\circledR}\end{array}$} & $\mathrm{CO}_{2}$ & $\begin{array}{c}0-10000 \\
\text { ppm }\end{array}$ & $1 \mathrm{ppm}$ & $\begin{array}{c}\text { Accuracy: } \\
\text { - } \pm 3 \% \mathrm{rdg} \pm 50 \mathrm{ppm} \\
\end{array}$ & \multirow{4}{*}[13]{,$[17]$} \\
\hline & $\mathrm{CO}$ & $0-500 \mathrm{ppm}$ & $<0.3 \mathrm{ppm}$ & $\begin{array}{c}\text { Accuracy: } \\
\text { - } \pm 2 \mathrm{ppm} \text { when } \mathrm{CO}<50 \mathrm{ppm} \\
\text { - } \pm 3 \% \text { rdg when CO }>50 \mathrm{ppm} \\
\end{array}$ & \\
\hline & $\mathrm{T}$ & -25 to $70^{\circ} \mathrm{C}$ & - & $\begin{array}{c}\text { Accuracy: } \\
\bullet \pm 0.3^{\circ} \mathrm{C} \\
\end{array}$ & \\
\hline & RH & $0 \%-100 \%$ & - & $\begin{array}{c}\text { Accuracy: } \\
\text { - } \pm 2 \% \text { when } \mathrm{RH}<80 \% \\
\text { - } \pm 3 \% \text { when } \mathrm{RH}>80 \% \\
\end{array}$ & \\
\hline \multirow{3}{*}{$\begin{array}{l}\text { TG-501 - } \\
\text { GrayWolf }^{\circledR}\end{array}$} & $\mathrm{NO}_{2}$ & $0-30 \mathrm{ppm}$ & $0.02 \mathrm{ppm}$ & - & \multirow{3}{*}[14]{} \\
\hline & $\mathrm{O}_{3}$ & $0-1 \mathrm{ppm}$ & $0.02 \mathrm{ppm}$ & - & \\
\hline & $\mathrm{T}$ & $-25^{\circ}$ to $70^{\circ} \mathrm{C}$ & - & $\begin{array}{l}\text { Accuracy: } \\
-\quad \pm 0.3^{\circ} \mathrm{C}\end{array}$ & \\
\hline \multirow{5}{*}{$\begin{array}{l}\text { YESAIR 8- } \\
\text { Channel IAQ } \\
\text { Monitor }\end{array}$} & $\mathrm{CO}_{2}$ & $\begin{array}{c}0-10000 \\
\text { ppm }\end{array}$ & - & $\begin{array}{c}\text { Accuracy: } \\
- \pm 2 \% \text { at } 20^{\circ} \mathrm{C} \text { and } 1 \text { bar }\end{array}$ & \multirow{5}{*}[18]{} \\
\hline & $\mathrm{CO}$ & $0-50 \mathrm{ppm}$ & - & - & \\
\hline & $\mathrm{NO}_{2}$ & $0-5 \mathrm{ppm}$ & - & - & \\
\hline & $\mathrm{T}$ & 0 to $50^{\circ} \mathrm{C}$ & - & - & \\
\hline & RH & $5 \%-95 \%$ & - & - & \\
\hline \multirow{3}{*}{$\begin{array}{l}\text { PC-3016A - } \\
\text { GrayWolf }^{\circledR}\end{array}$} & PM & $\begin{array}{l}<8000000 \\
\text { Particles } / \mathrm{ft}^{3}\end{array}$ & $\begin{array}{c}<1 \text { Count } / 5 \\
\text { minutes }\end{array}$ & $\begin{array}{c}\text { Counting Efficiency: } \\
\text { - } 50 \% \text { for particles with } 0.3 \mu \mathrm{m} \\
\text { - } 100 \% \text { for particles }>0.45 \mu \mathrm{m} \\
\text { Uncertainty: } \\
\text { - } 2.5 \% \\
\end{array}$ & \multirow{3}{*}[15]{} \\
\hline & $\mathrm{T}$ & 0 to $50^{\circ} \mathrm{C}$ & - & $\begin{array}{c}\text { Accuracy: } \\
\bullet \quad \pm 0.5^{\circ} \mathrm{C} \\
\end{array}$ & \\
\hline & RH & $15 \%-90 \%$ & - & $\begin{array}{l}\text { Accuracy: } \\
\bullet \pm 5 \%\end{array}$ & \\
\hline
\end{tabular}

Before the intercomparison tests, the response of commercial devices to several air pollutants was validated, through controlled atmospheres prepared with certified standard gas mixture or tested with reference methods. This procedure was repeated at the end of each intercomparison. The controlled atmosphere test comprises assessing the monitoring equipment performance when exposed to known concentrations of several gas pollutants. The GrayWolf ${ }^{\circledR}$ PC-3016A performance was verified against the reference method for $\mathrm{PM}_{10}$ and $\mathrm{PM}_{2.5}$ measurements. The measurements given by the GrayWolf ${ }^{\mathbb{B}}$ PC-3016A were compared with the low-volume sampler TCR-TECORA (certified equipment for $\mathrm{PM}_{10}$ and $\mathrm{PM}_{2.5}$ sampling). The TRC-TECORA sampling was performed through quartz filters in agreement with the EN 12341:2014 guidelines [19]. 


\section{RESULTS AND DISCUSSION}

\subsection{Intercomparation test results}

The commercial IAQ instruments showed a stable signal during the tests with controlled atmospheres. For example, the variations between the GrayWolf ${ }^{\mathbb{B}}$ (IQ-610 and TG-501) and the controlled atmospheres ([commercial monitor conc. - certified gas conc.]/[certified gas conc.]) were $-1.2 \%$ for $\mathrm{CO}, 2.5 \%$ for $\mathrm{CO}_{2}$ and $2.6 \%$ for $\mathrm{NO}_{2}$. The YESAIR showed higher variations than the GrayWolf ${ }^{\mathrm{B}}$, with deviations of $-5.7 \%$ for $\mathrm{CO},-9 \%$ for $\mathrm{CO}_{2}$ and $-12.7 \%$ for $\mathrm{NO}_{2}$. The variation between the $\mathrm{PM}_{10}$ concentrations measured by the GrayWolf ${ }^{\circledR} \mathrm{PC}$ $3016 \mathrm{~A}$ and the TCR-TECORA was $9.9 \%([\mathrm{TCR}-\mathrm{TECORA}]=0.51 \times[\mathrm{PC}-3016 \mathrm{~A}]+25.08$ $\left.\mathrm{R}^{2}=0.95\right)$.

Table 3 summarises the key statistics and linear regression parameters for all the intercomparison tests. The overall daily variations of the several pollutants measured by the sensor boxes were similar to those found by the commercial monitors. As an example, Fig. 4 shows the response given by the sensor box and the commercial monitors to the $\mathrm{PM}_{10}, \mathrm{PM}_{2.5}$, $\mathrm{CO}_{2}$ and $\mathrm{CO}$ variations in the living room. The living room sensor box performance for these pollutants was reasonable, with $\mathrm{R}^{2}$ ranging from 0.87 to 1 . The $\mathrm{PM}_{10}$ was the parameter where the greatest dispersion occurred in the living room, however, the 24-hour averages for this location are in the same order of magnitude, $22 \mu \mathrm{g} / \mathrm{m}^{3}$ for PC-3016A and $29 \mu \mathrm{g} / \mathrm{m}^{3}$ for the sensor box.

Table 3: Statistics and regression parameters from the inter comparison tests.

\begin{tabular}{|c|c|c|c|c|c|c|c|}
\hline \multirow{2}{*}{ Pollutant } & \multirow{2}{*}{ Site } & \multicolumn{3}{|c|}{ Commercial equipment } & \multicolumn{2}{|c|}{ Sensor box } & \multirow{2}{*}{$\begin{array}{c}\text { Linear regression } \\
\text { parameters } * *\end{array}$} \\
\hline & & equipment & mean* & $\min -\max *$ & mean* & $\min -\max *$ & \\
\hline \multirow{2}{*}{$\begin{array}{c}\mathrm{CO} \\
\left(\mu \mathrm{g} / \mathrm{m}^{3}\right)\end{array}$} & \multirow{2}{*}{$\begin{array}{l}\text { living } \\
\text { room }\end{array}$} & IQ-610 & 695 & 0-3019 & \multirow{2}{*}{1720} & \multirow{2}{*}{$466-4468$} & $\begin{array}{c}y=0.93 x-1169 \\
R^{2}=0.960\end{array}$ \\
\hline & & YESAIR & 1396 & $395-4126$ & & & $\begin{array}{c}\mathrm{y}=1.03 \mathrm{x}-460 \\
\mathrm{R}^{2}=0.976\end{array}$ \\
\hline \multirow{4}{*}{$\begin{array}{c}\mathrm{CO}_{2} \\
(\mathrm{ppm})\end{array}$} & \multirow{2}{*}{$\begin{array}{l}\text { living } \\
\text { room }\end{array}$} & IQ-610 & 947 & $538-1428$ & \multirow{2}{*}{1084} & \multirow{2}{*}{$682-1550$} & $\begin{array}{c}\mathrm{y}=1.03 \mathrm{x}-174 \\
\mathrm{R}^{2}=0.996\end{array}$ \\
\hline & & YESAIR & 904 & $526-1344$ & & & $\begin{array}{c}\mathrm{y}=0.94 \mathrm{x}-113 \\
\mathrm{R}^{2}=0.9957\end{array}$ \\
\hline & \multirow{2}{*}{ bedroom } & IQ-610 & 755 & $553-971$ & \multirow{2}{*}{856} & \multirow{2}{*}{$663-1077$} & $\begin{array}{c}\mathrm{y}=1.05 \mathrm{x}-147 \\
\mathrm{R}^{2}=0.9960\end{array}$ \\
\hline & & YESAIR & 706 & $535-895$ & & & $\begin{array}{c}\mathrm{y}=0.90 \mathrm{x}-64.8 \\
\mathrm{R}^{2}=0.9930\end{array}$ \\
\hline \multirow{2}{*}{$\begin{array}{c}\mathrm{NO}_{2} \\
\left(\mu \mathrm{g} / \mathrm{m}^{3}\right)\end{array}$} & \multirow{2}{*}{$\begin{array}{l}\text { living } \\
\text { room }\end{array}$} & TG-501 & 0 & $0-10$ & \multirow{2}{*}{4} & \multirow{2}{*}{$0-16$} & - \\
\hline & & YESAIR & 0 & - & & & - \\
\hline \multirow{2}{*}{$\begin{array}{c}\mathrm{PM}_{10} \\
\left(\mu \mathrm{g} / \mathrm{m}^{3}\right)\end{array}$} & $\begin{array}{l}\text { living } \\
\text { room }\end{array}$ & PC-3016A & 22 & $18-33$ & 29 & $24-40$ & $\begin{array}{c}\mathrm{y}=0.97 \mathrm{x}-6.58 \\
\mathrm{R}^{2}=0.875\end{array}$ \\
\hline & bedroom & PC-3016A & 41 & $39-44$ & 15 & - & $\begin{array}{c}\mathrm{y}=2.20 \mathrm{x}+5.49 \\
\mathrm{R}^{2}=0.727\end{array}$ \\
\hline \multirow{2}{*}{$\begin{array}{c}\mathrm{PM}_{2.5} \\
\left(\mu \mathrm{g} / \mathrm{m}^{3}\right)\end{array}$} & $\begin{array}{c}\text { living } \\
\text { room }\end{array}$ & PC-3016A & 14 & $11-22$ & 24 & $19-35$ & $\begin{array}{c}\mathrm{y}=0.57 \mathrm{x}+0.42 \\
\mathrm{R}^{2}=0.923\end{array}$ \\
\hline & bedroom & PC-3016A & 10 & $9-11$ & 7 & - & $\begin{array}{c}\mathrm{y}=0.55 \mathrm{x}+5.58 \\
\mathrm{R}^{2}=0.761\end{array}$ \\
\hline $\begin{array}{c}\mathrm{O}_{3} \\
\left(\mu \mathrm{g} / \mathrm{m}^{3}\right)\end{array}$ & $\begin{array}{l}\text { living } \\
\text { room }\end{array}$ & TG-501 & 5 & $0-20$ & 35 & $30-47$ & $\begin{array}{c}\mathrm{y}=1.12 \mathrm{x}-33.9 \\
\mathrm{R}^{2}=0.412\end{array}$ \\
\hline
\end{tabular}

* $\mathrm{CO}$ and $\mathrm{CO}_{2}: 8$ hours average; $\mathrm{NO}_{2}$ and $\mathrm{O}_{3}: 1$ hour average; $\mathrm{PM}_{10}$ and $\mathrm{PM}_{2.5}: 24$ hours average.

** $\mathrm{y}$-commercial equipment, $\mathrm{x}-$ sensor box. 

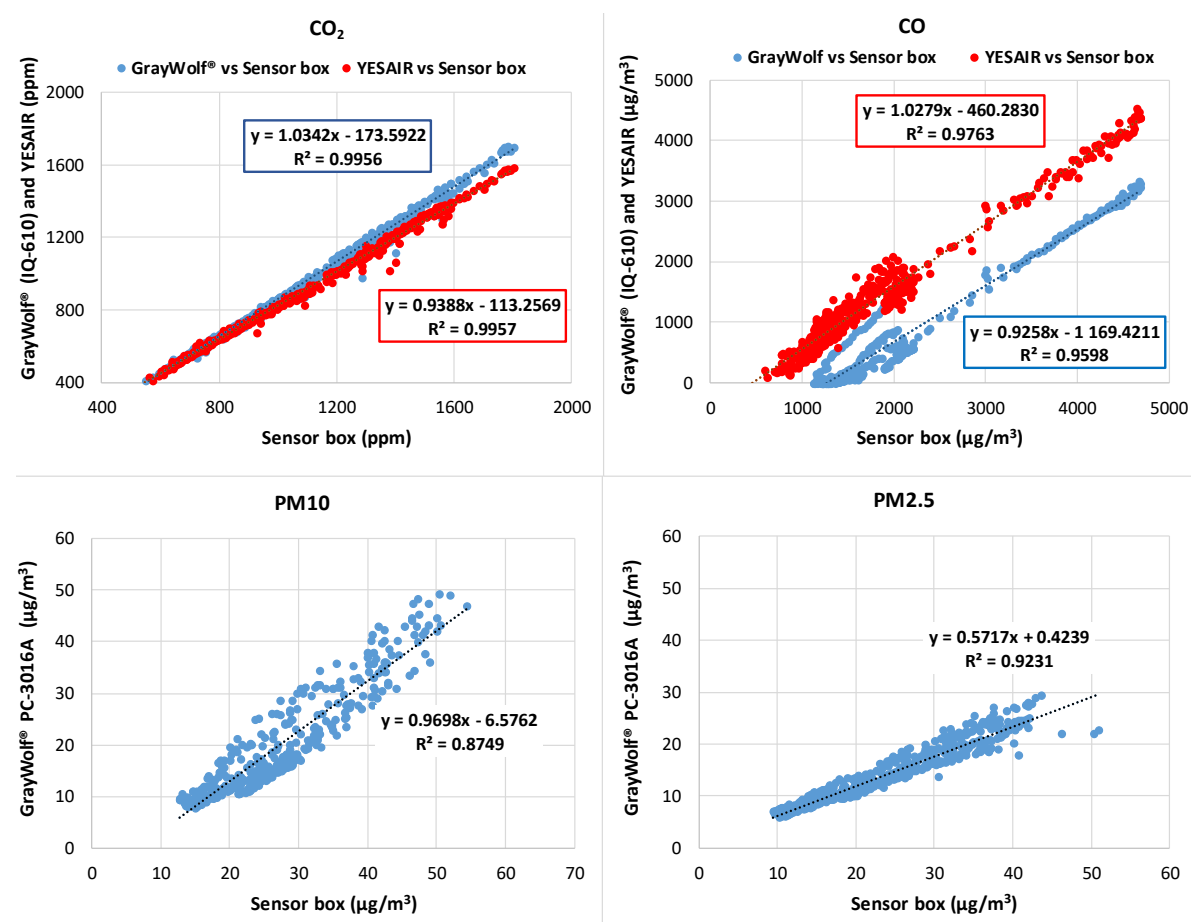

Figure 4: $\quad \mathrm{CO}_{2}, \mathrm{CO}, \mathrm{PM}_{10}$ and $\mathrm{PM}_{2.5}$ levels measured by the living room sensor box versus the commercial monitors $\mathrm{CO}_{2}, \mathrm{CO}, \mathrm{PM}_{10}$ and $\mathrm{PM}_{2.5}$ levels measured by the living room sensor box versus the commercial monitors.

\subsection{Indoor monitoring results}

In order to analyse the indoor temporal patterns of the air quality $\left(\mathrm{PM}_{10}, \mathrm{PM}_{2.5}, \mathrm{CO}_{2}, \mathrm{CO}\right.$, $\mathrm{NO}_{2}$, oxidising substances, $\mathrm{O}_{3}$ ) and meteorology (temperature and relative humidity) in different parts of the selected homes (three bedrooms and three living rooms) the following approaches were considered: i) time series; ii) monthly averages; iii) weekdays and weekends averages; and iv) daily averages profiles.

In Fig. 5 is presented the average temporal distribution (from 5 to 15 minutes periods) of temperature, relative humidity, $\mathrm{PM}_{10}, \mathrm{PM}_{2.5}$ and $\mathrm{CO}_{2}$ for the bedroom 1 (BR1) between 5th Sept. 2019 and 16th Mar. 2020.

The values obtained for all monitoring parameters and in all evaluated places, present in the first 15 days, a different variation pattern when compared with the remaining measured period. This could be related to different behaviour of the house users since in this period were registered meteorological conditions (i.e. high outdoor temperatures and solar radiation) favourable to higher ventilation rates due to window opening. Furthermore, despite a field based calibration procedure being considered to calibrate the sensors comparing its results with the data from the reference equipment (Section 2.2 of this work), the sensors revealed the need to spin-up at least the first 15 days. By doing so, the sensors had the opportunity to adapt to the meteorological conditions (e.g. temperature and relative humidity) registered in the analysed buildings, avoiding potential human errors of home users as well as inadequate home locations to measure a representative IAQ and meteorological values of the study areas. 

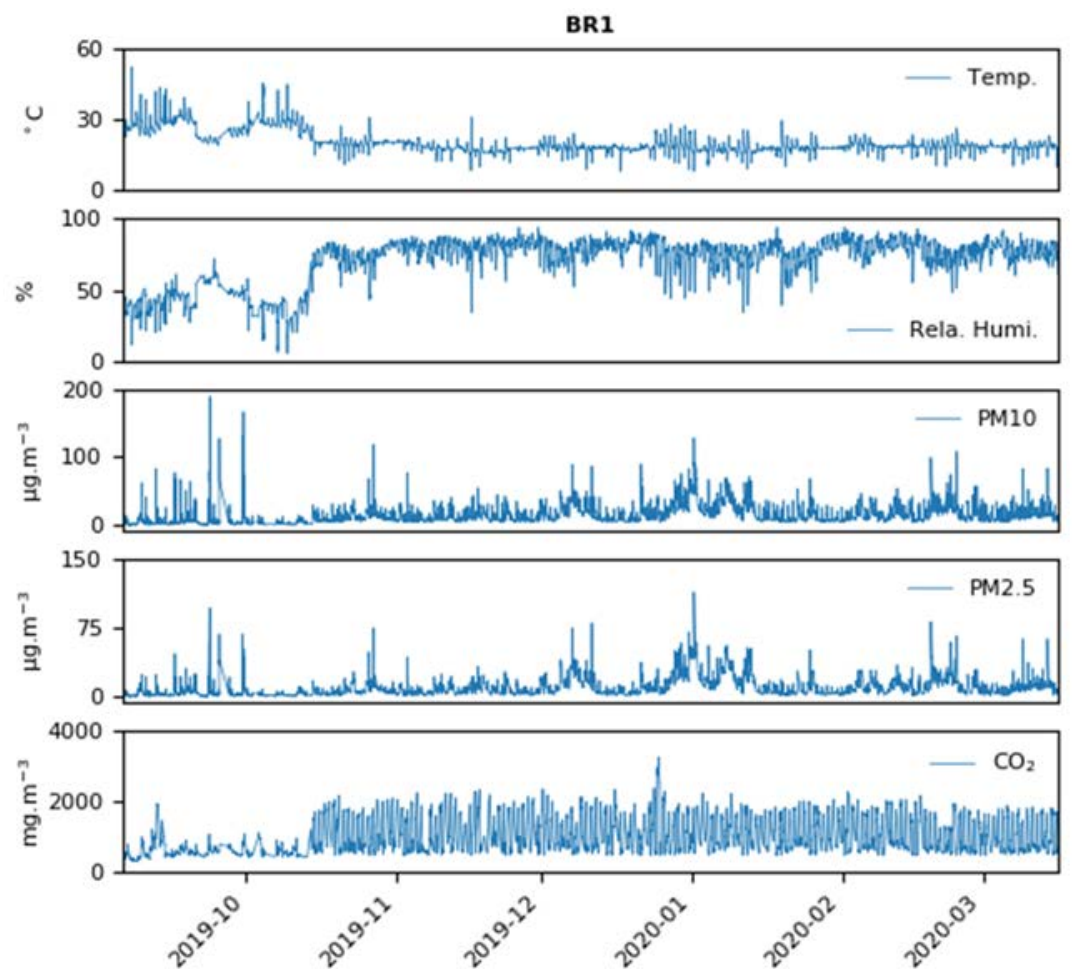

Figure 5: Hourly values of temperature, relative humidity, $\mathrm{PM}_{10}, \mathrm{PM}_{2.5}$ and $\mathrm{CO}_{2}$ for the bedroom 1 (BR1).

Concerning the seasonal pattern (autumn: Sept., Oct. and Nov.; winter: Dec., Jan. and Feb.; Spring: Mar.), Fig. 6 shows the monthly averages of temperature, relative humidity, $\mathrm{PM}_{10}, \mathrm{PM}_{2.5}$ and $\mathrm{CO}_{2}$ for the bedrooms (BR1, BR2 and BR3) from September 2019 to March 2020 (seven-month period).

As expected, the temperature and relative humidity registered a negative correlation coefficient (between -0.88 and -0.98), as such, when the temperature increased the relative humidity decreased. Results show that BR1 recorded the lowest temperatures (from $18^{\circ} \mathrm{C}$ to $26^{\circ} \mathrm{C}$ ) and the highest relative humidity (between $46 \%$ and $80 \%$ ). However, BR1 presented the largest $\mathrm{CO}_{2}$ concentrations (ranging from $591 \mathrm{mg}$ to $1127 \mathrm{mg}$ ), since human breath is the main indoor source of this pollutant, indicating an inadequate air ventilation. In addition, the measured temperatures $\left(\approx\right.$ less $1^{\circ} \mathrm{C}$ than $\mathrm{BR} 2$ and $\left.\mathrm{BR} 3\right)$ and relative humidity $(\approx 8 \%$ higher than BR2 and BR3) in BR1 revealed that it receives less direct solar radiation when compared with BR2 and BR3. The indoor $\mathrm{PM}_{10}$ and $\mathrm{PM}_{2.5}$ concentrations of the analysed bedrooms were influenced by outdoor air pollution levels, ventilation rate, indoor sources (e.g. heating equipment's and cooking), occupant activities (e.g. house cleaning), biological origin (e.g. indoor plants) and house air fresheners. The bedrooms recorded similar season patterns (correlation coefficient between 0.64 and 0.73 ) and PM average concentrations. In January, when the lowest indoor temperatures were recorded, the highest $\mathrm{PM}_{10}\left(25 \mu \mathrm{g} . \mathrm{m}^{-3}\right)$ and $\mathrm{PM}_{2.5}$ $\left(19 \mu \mathrm{g} \cdot \mathrm{m}^{-3}\right)$ concentrations were registered in BR2 due to a strong particle source from pellet heating stove used to warm the different parts of the house. 

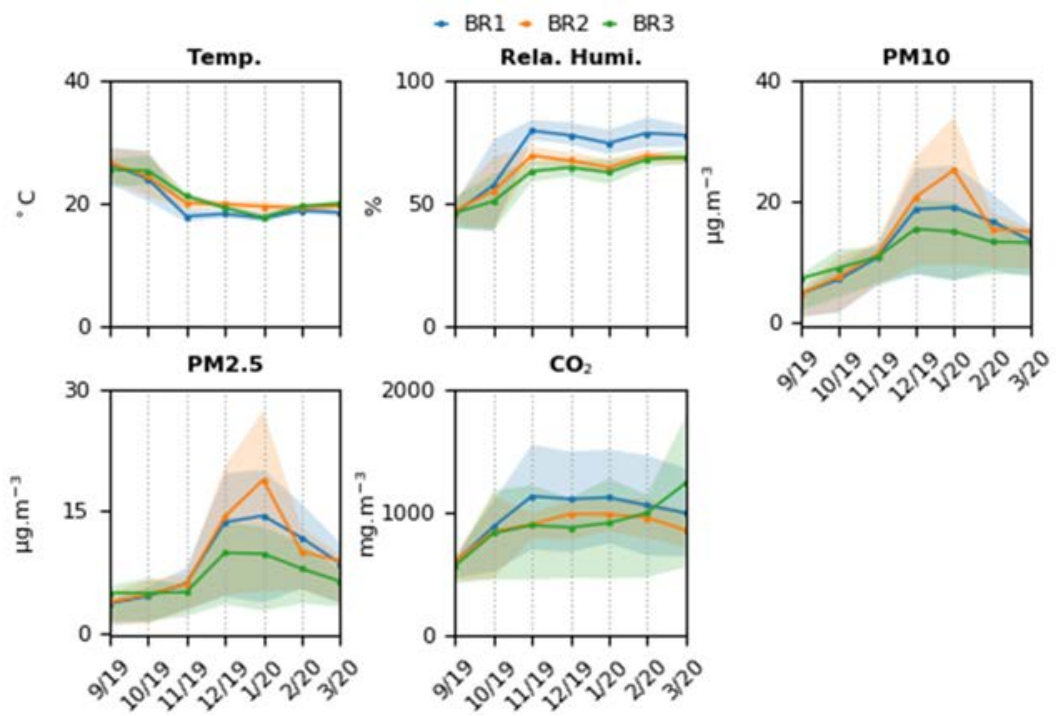

Figure 6: Monthly averages of temperature, relative humidity, $\mathrm{PM}_{10}, \mathrm{PM}_{2.5}$ and $\mathrm{CO}_{2}$ for the bedrooms (BR1, BR2 and BR3). The shaded areas in the figure represent the $75 \%$ confidence interval.

Aiming to evaluate the weekly indoor profiles, Fig. 7 displays the corresponding averages (weekdays and weekends) for the temperature, relative humidity, $\mathrm{PM}_{10}, \mathrm{PM}_{2.5}$ and $\mathrm{CO}_{2}$ for each bedroom.
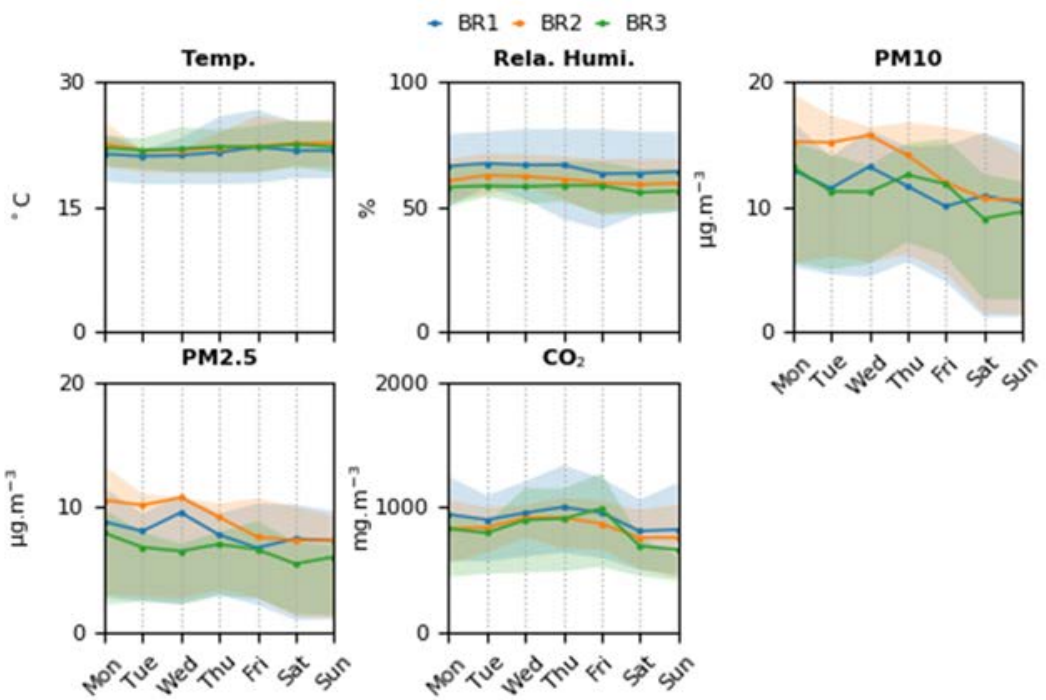

Figure 7: Temperature, relative humidity, $\mathrm{PM}_{10}, \mathrm{PM}_{2.5}$ and $\mathrm{CO}_{2}$ averages, during weekdays and weekends, for the bedrooms (BR1, BR2 and BR3). The shaded areas in the figure represent the $75 \%$ confidence interval. 
The three bedrooms recorded similar temperatures and relative humidity between them and from Monday to Sunday, showing that the indoor meteorological parameters are mainly affected by the outdoor weather conditions. The $\mathrm{PM}_{10}$ and $\mathrm{PM}_{2.5}$ levels were highly influenced by human activity patterns, since these pollutants recorded the lowest values (Saturday and Sunday) when the $\mathrm{CO}_{2}$ concentrations were also lower (from $661 \mathrm{mg} \cdot \mathrm{m}^{-3}$ to $810 \mathrm{mg} \cdot \mathrm{m}^{-3}$ ). Both BR1 and BR2 recorded the highest PM concentrations on Wednesday ( $\left.\mathrm{PM}_{10}: 13-16 \mu \mathrm{g} \cdot \mathrm{m}^{-3} ; \mathrm{PM}_{2.5}: 10-11 \mu \mathrm{g} \cdot \mathrm{m}^{-3}\right)$ while in the $\mathrm{BR} 3$ the largest values were registered on Monday $\left(\mathrm{PM}_{10}: 13 \mu \mathrm{g} \cdot \mathrm{m}^{-3} ; \mathrm{PM}_{2.5}: 8 \mu \mathrm{g} \cdot \mathrm{m}^{-3}\right)$. In fact, for all the analysed bedrooms these periods usually correspond with the cleaning days, which include vacuuming and dusting. This type of human activity tends to stir up a lot of the dust that has settled on floor and furniture.

Fig. 8 provides the daily average profiles of temperature, relative humidity, $\mathrm{PM}_{10}, \mathrm{PM}_{2.5}$, $\mathrm{CO}_{2}, \mathrm{CO}, \mathrm{NO}_{2}$, oxidizing substances and $\mathrm{O}_{3}$ for the living rooms (LR1, LR2 and LR3).

- LR1 - LR2 - LR3
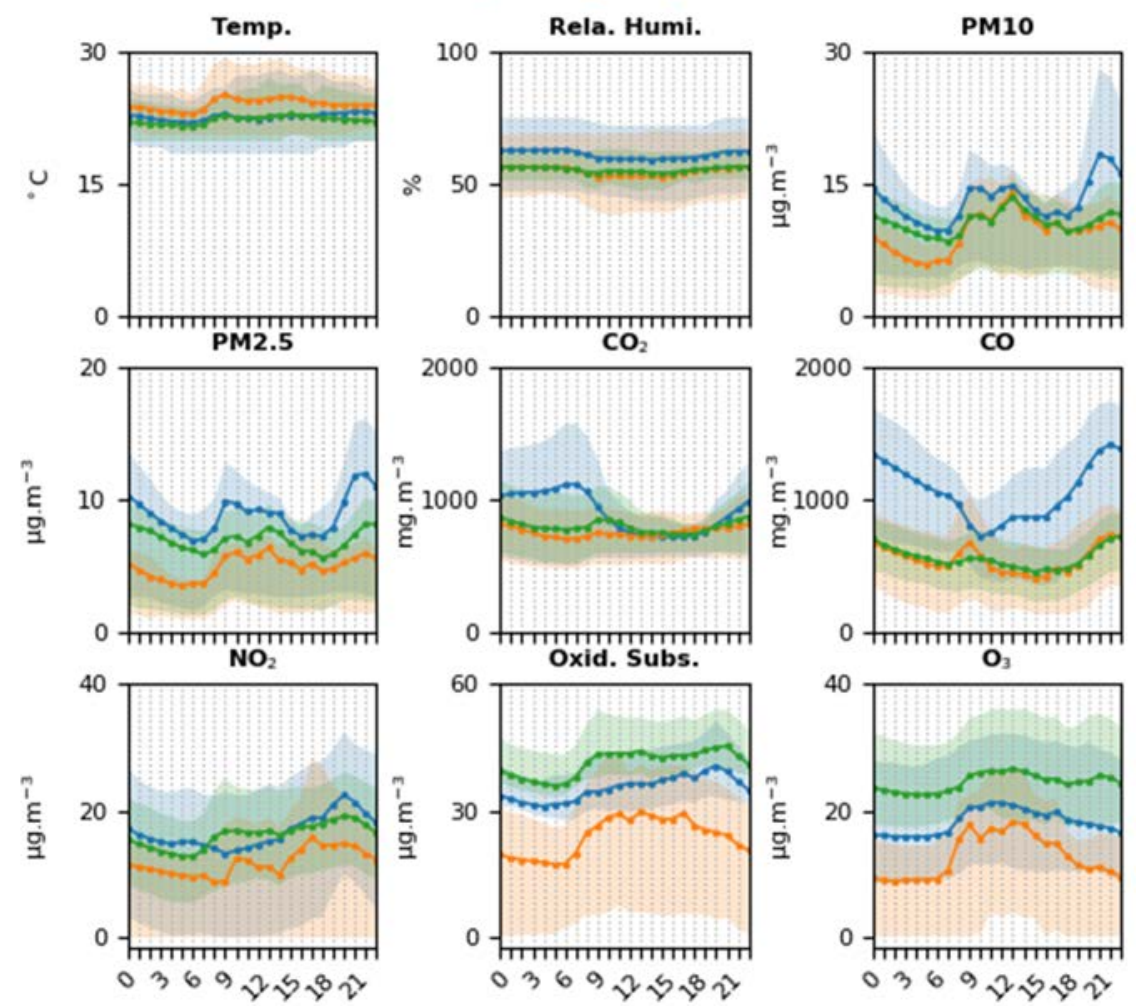

Figure 8: Daily average profiles of temperature, relative humidity, $\mathrm{PM}_{10}, \mathrm{PM}_{2.5}, \mathrm{CO}_{2}, \mathrm{CO}$, $\mathrm{NO}_{2}$, Oxid. Subs. and $\mathrm{O}_{3}$ for the living rooms (LR1, LR2 and LR3). The shaded areas in the figure represent the $75 \%$ confidence interval.

As noted by the analysis of the air quality and meteorological patterns during the different days of the week (Fig. 7), the living rooms (LR1, LR2 and LR3) registered similar daily average profiles for these parameters (correlation coefficient higher than 0.84). Lower 
pollutants concentration in LR2 can be explained by the influence of outdoor concentrations and natural ventilation, due to the presence of the housekeeper every morning.

The living rooms recorded identical daily variation of $\mathrm{PM}_{10}$ and $\mathrm{PM}_{2.5}$ levels with a correlation coefficient ranging from 0.51 to 0.64 (i.e. LR1 vs LR2; LR2 vs LR3; and LR2 vs LR3). For these pollutants, the areas in study were affected by the outdoor air pollution concentrations. LR1 is located next to a road with high road traffic volume and close to an important chemical industrial area (about $5 \mathrm{~km}$ away), registering the highest PM ( $\mathrm{PM}_{10}: 10$ $18 \mu \mathrm{g} . \mathrm{m}^{-3} ; \mathrm{PM}_{2.5}: 6.9-12 \mu \mathrm{g} . \mathrm{m}^{-3}$ ) levels. On the other hand, LR2 is placed in peripheral residential area near the coastline, where the main atmospheric emission sources are from the domestic activities, recording the lowest $\mathrm{PM}_{10}\left(6-14 \mu \mathrm{g} . \mathrm{m}^{-3}\right)$ and $\mathrm{PM}_{2.5}\left(3.5-6.4 \mu \mathrm{g} . \mathrm{m}^{-3}\right)$ concentrations. LR1 is also the one with the lowest ventilation rate during night period as indicated the $\mathrm{CO}_{2}$ and $\mathrm{CO}$ concentrations. Carbon monoxide peak concentrations at 9 a.m. was recorded in LR2 (683 mg. $\left.\mathrm{m}^{-3}\right)$ and LR3 $\left(558 \mathrm{mg} . \mathrm{m}^{-3}\right)$ due to indoor combustion sources (e.g. heating and cooking).

The daily patterns of $\mathrm{NO}_{2}$ and oxidizing substances are similar in LR1 and LR2 $(\mathrm{r}=0.74)$, while for $\mathrm{O}_{3}$, the LR1 and LR3 registered equivalent variation $(\mathrm{r}=0.72)$. Regarding these pollutants, the highest air pollution levels were recorded in LR3 with the concentrations increasing in the early morning (between 6 a.m. and 9 a.m.), stabilizing throughout the day (from 9 a.m. to 6 p.m.) and reaching a minimum level at around 6 a.m. Combustion processes from indoor (e.g. cooking and heating) and outdoor (e.g. road transport) sources are the main causes of $\mathrm{NO}_{2}$ and oxidizing substances, while the $\mathrm{O}_{3}$ is formed by photochemical reactions between NOx and VOC. However, during the night, this pollutant reacts chemically with components of the house (e.g. furniture) and other chemicals in the air, reducing indoor $\mathrm{O}_{3}$ levels.

\section{FINAL REMARKS}

This study evaluates indoors environment, namely air quality and weather conditions, in different housing compartments using low-cost sensors. Monitoring data was collected over approximately seven months covering autumn, winter, and springtime.

Intercomparision field tests showed that low-cost sensors give a quite reasonable response compared to the commercial reference equipment, with $\mathrm{R}^{2}$ ranging from 0.87 to 1 for living rooms and $\mathrm{R}^{2}$ ranging from 0.73 to 1 for bedrooms.

The study showed that indoor conditions are strongly influenced by the activity and behaviour of the residents:

i) There is a negative correlation coefficient between temperature and relative humidity;

ii) $\mathrm{PM}_{10}$ and $\mathrm{PM}_{2.5}$ levels are lower at Saturday and Sunday, when the $\mathrm{CO}_{2}$ concentrations are also lower, probably associated to better ventilation. The indoor PM concentrations were affected by outdoor air pollution levels, ventilation rate, indoor sources (e.g. heating and cooking), time-activity patterns of occupants (e.g. housekeeper);

iii) Average concentration of pollutants, temperature and relative humidity recorded similar behaviour for weekdays and weekends, in the three houses, showing that the indoor parameters are strongly affected by the outdoor weather conditions;

iv) The daily average profiles are directly with resident's behaviour, indoors activities (heating, cooking and cleaning) as well as the ventilation of compartments.

Daily pollutants concentration patterns show also that weather conditions, the geographic location and outdoor pollution sources could strongly affect indoor air quality. 


\section{ACKNOWLEDGEMENTS}

The authors acknowledge for the financial support to Smart Green Homes Project [POCI-010247-FEDER007678], a co-promotion between Bosch Termotecnologia S.A. and the University of Aveiro. It is financed by Portugal 2020 under the Competitiveness and Internationalization Operational Program, and by the European Regional Development Fund. Thanks, are also due to FCT/MCTES for the financial support to CESAM (UID/AMB/50017/2020+UIDB/50017/2020).

\section{REFERENCES}

[1] Cohen, A.J. et al., Estimates and 25-year trends of the global burden of disease attributable to ambient air pollution: an analysis of data from the Global Burden of Diseases Study 2015. Lancet, 389, pp. 1907-1918, 2017.

[2] Schweizer, C. et al., Indoor time-microenvironment-activity patterns in seven regions of Europe. Journal of Exposure Science and Environmental Epidemiology, 17, pp. 170-81, 2007.

[3] Solomon, P.A. et al., Air pollution and health: bridging the gap from sources to health outcomes: conference summary. Air Quality, Atmosphere \& Health, 5, pp. 9-62, 2012.

[4] World Health Organisation, Burden of disease from household air pollution for 2016, 2018. https://www.who.int/airpollution/data/HAP_BoD_results_May2018_final.pdf, p. 4. Accessed on: 7 Jan. 2020.

[5] World Health Organisation, WHO guidelines for indoor air quality: selected pollutants. WHO, Regional Office for Europe: Bonn, 2010.

[6] Jardim, D. et al., Metodologia de avaliação da qualidade do ar interior em edifícios de comércio e serviços no âmbito da Portaria 353-A/2013. Agência Portuguesa do Ambiente and Direção Geral da Saúde: Portugal, 2015.

[7] US Environmental Protection Agency, Report to Congress on Indoor Air Quality: Volume II - Assessment and Control of Indoor Air Pollution. US Environmental Protection Agency: Washington, D.C., 1989.

[8] Rai, A.C. et al., End-user perspective of low-cost sensors for outdoor air pollution monitoring. Science of the Total Environment, pp. 607-705, 2017.

[9] Borrego, C. et al., Assessment of air quality microsensors versus reference methods: The EuNetAir Joint Exercise - Part II. Atmospheric Environment, 193, pp. 127-42, 2018.

[10] Liu, X. et al., Low-cost sensors as an alternative for long-term air quality monitoring. Environmental Research, 185, 2020.

[11] Chojer, H., Branco, P.T.B.S., Martins, F.G., Alvim-Ferraz, M.C.M. \& Sousa, S.I.V., Development of low-cost indoor air quality monitoring devices: Recent advancements, Science of the Total Environment, 727, 2020. DOI:10.1016/j.scitotenv.2020.138385.

[12] Mueller, M., Meyer, J. \& Hueglin, C., Design of an ozone and nitrogen dioxide sensor unit and its long-term operation within a sensor network in the city of Zurich. Atmospheric Measurement Techniques, 10, pp. 3783-3799, 2017.

[13] GrayWolf Sensing Solutions, AdvancedSense ${ }^{\circledR}$ - Indoor Air Quality Meters Brochure 2014. GraywolfsensingCom, http://www.wolfsense.com/pdf/GrayWolf-Indoor-AirQuality-IAQ-Meter-Brochure-lo.pdf, p. 4. Accessed on: 13 Nov. 2019.

[14] GrayWolf Sensing Solutions, AdvancedSense ${ }^{\circledR}$ - Toxic Gas Test Meters Brochure 2014. https://graywolfsensing.com/wp-content/pdf/GrayWolfTOX.pdf, p. 4. Accessed on: 13 Nov. 2019. 
[15] GrayWolf Sensing Solutions, PC-3016A (6-Channel Particle Counter) 2018. GraywolfsensingCom, https:/graywolfsensing.com/wp-content/pdf/GrayWolfPC3016AParticulateMeterBrochure 918.pdf. Accessed on: 25 Mar. 2020.

[16] Lighthouse Worldwide Solutions, Operating Manual - HANDHELD 2016, 3016, 5016, 2007. https://www.golighthouse.com/media/files/product/2480834001_R7_(OpMan_H2016_H3016_H5016_Gen_F)_Letter.pdf. Accessed on: 26 Mar. 2020 .

[17] GrayWolf Sensing Solutions, GRAYWOLF SPECIFICATIONS 2016. Graywolfsensing Com, http://www.wolfsense.com/pdf/specs/electrochemicals.pdf. Accessed on: 25 Mar. 2020.

[18] Critical Environment Technologies Canada Inc., Portable Indoor Air Quality Instruments and Smart Sensor Specifications 2018. Critical-EnvironmentCom, https://www.critical-environment.com/media/download/guides/IAQ-SensorSpecification.pdf. Accessed on: 25 Mar. 2020.

[19] Portuguese Institute for Quality, NP EN 12341:2014-Ambient Air-Standard Gravimetric Measurement Method for the Determination of the $\mathrm{PM}_{10}$ or $\mathrm{PM}_{2.5}$ Mass Concentration of Suspended Particulate Matter. IPQ: Almada, 2014. 